\title{
SOME KEY PITFALLS IN LITERARY TRANSLATION
}

\author{
Silvana Neshkovska ${ }^{1}$, Sonja Kitanovska-Kimovska ${ }^{2}$
}

\begin{abstract}
Literary translation is considered to be the most challenging type of translation despite the numerous rewards it offers both to translators themselves and the humanity in general.

Research shows that numerous factors contribute to this state of affairs. The differences between the source and target language and culture surely account for a large portion of the challenges that arise in doing literary translation. In addition, literature abounds with diverse literary genres - the most predominant ones being prose, poetry and plays. Each of them features a set of specific traits which when transferred into the target language need to be addressed with special deliberation. Nevertheless, a plethora of issues that literary translators grapple with are common to all three literary genres. These encompass translating the title, the culture-specific terms, slang, expletives, subtext, style, etc.
\end{abstract}

This paper is intended to shed some light on these common pitfalls that recur in translating diverse literary genres, and is intended to be of assistance to novice literary translators. What makes the study particularly valid and authentic is the fact that the points discussed are illustrated with instances of translation solutions extracted from empirical studies of Macedonian translations of literary works originally written in English.

Keywords: literary translation, title, slang, expletives

\section{Introduction}

Literary translation traces its origins back to ancient times probably to when the famous epic of Gilgamesh was translated in several different languages (e.g. Sumerian, Babylonian, Arcadian, etc.). This tradition proceeded with the translation of the Bible from Hebrew to Ancient Greek in the $2^{\text {nd }}$ century AD and was particularly intensified with the extensive translation practice of the ancient Romans. The Romans endeavoured to recreate the extremely rich and inspiring Greek literature into Latin, and spared no efforts in translating the exquisite works of the Ancient Greek writers and philosophers (Arsova-Nikolikj, 1999).

1. Ph.D, "St. Kliment Ohridski” University-Bitola, e-mail: silvana.neskovska@uklo.edu. mk, ORCID: 0000-0003-4417-7783

2. Ph.D., "Ss. Cyril and Methodius" University-Skopje, e-mail: sonjakitanovska@flf.ukim. edu.com, ORCID: 0000-0003-0037-0434 
Nowadays well into the $21^{\text {st }}$ century, literary translation is still a very relevant human activity. What has kept it alive in the course of the centuries are the numerous benefits it offers not just to humanity at large but also to those who are enthusiastic enough to dedicate their lives and careers to literary translation. For humanity literary translation serves as a bridge between nations, across which distinct traditions, values, customs are transported and made available to wide audiences. But for literary translation, numerous literary masterpieces would have had only a limited reach and many appreciators of the written word would have been deprived of the privilege to rejoice in their splendour. On a personal level, literary translation brings benefits to translators not so much in the form of monetary gains or fame as in the form of an intensified and deepened intellectual challenge. The dedicated literary translator is involved in continuous quests, which entail not just consulting dictionaries, but consulting native speakers, authors, editors, publishers, other translators, books, magazines, the Internet, etc. All of that, undoubtedly, requires a great deal of patience and perseverance.

Nevertheless, irrespective of what genre is translated (prose, poetry or plays), literary translation is undoubtedly a very demanding type of translation. Apart from the differences in structure, i.e. form (poetry is written in lines and stanzas, novels are organised in chapters and paragraphs, and dialogues and monologues are the main building blocks of plays), each genre has its distinctive traits, some of which cannot be easily transferred from the source to the target language. In addition, translators should be mindful of the overarching need of recreating successfully the same or approximately the same aesthetic appeal of the original piece in the translated text, and its potential to elevate and enlighten the spirit of the respective readership.

The problems, very often, start even with the title itself. Given that the title is the very first thing that either catches or puts off the reader's attention, it is vital that translators render it correctly and appropriately. Other thorny issues include the translation of culture-specific terms, slang, puns, and expletives. Also, the author's style and subtext are among those issues which, if not handled properly, seriously undermine the value of the translated text.

The paper at hand draws on the findings of previous theorists who have dealt with the issue of literary translation such as Newmark (1988), Landers (2001), Paul (2009), Venuti (2008), Delabastita (1997), and Fernandez (2006).

The purpose of the study is to underline some key pitfalls that are common to translating prose, poetry and plays. To illustrate the main points, instances of translation solutions extracted from empirical studies of Macedonian translations of literary works originally written in English are presented and discussed. We believe the insights discussed in the paper are particularly useful for emerging literary translators who have already embarked or are about to embark on the 
journey of translating literature. Landers's (2001, p. 28) contention that "it is unfortunate that there is no mentorship programs for literary translators and precious little training is available for would-be literary translation in the handful of translation programs and universities" lends a perfect justification for this study.

\section{Translating literature}

Translation theorists seem to be in agreement that in order for a translator to do a successful literary translation he/she should meet several basic but vital requirements. Thus, first and foremost, literary translators should have a very solid grasp of both the source and the target language and culture. This means that they should be prone to lifelong learning and should put an effort to be exposed as much as possible to both languages and cultures. This certainly entails using all possible means such as films, books, magazines, stays in the foreign country where the foreign language is spoken, contact with native speakers, etc., in order to keep pace with all the relevant linguistic and societal changes and trends (Landers, 2001).

In addition, irrespective of what literary genre the translator has selected to work on, it is of paramount importance that they familiarise themselves well with the text by rereading it a number of times. This provides the translator with a preview of the translational challenges that await him/her in that specific work. Translators are also advised to read other works of the same author as well as the author's biography so that they would learn more about the author and what influenced his/her writing. All these are vital steps in translating any literary piece efficiently, and by taking the time to consider them properly, the translator is boosting his/her chances of success (Landers, 2001).

Another salient recommendation which translation theorists repeatedly make to literary translators is that, from the very outset, they should decide whether they would apply the domestication or foreignisation approach in their translation. According to Venuti (2008, p. 15) domestication is "an ethnocentric reduction of the foreign text to receiving cultural values, bringing the author back home" whereas, foreignisation is "an ethno deviant pressure on those values to register the linguistic and cultural differences of the foreign text, sending the reader abroad" (op. cit.). Newmark (1988) calls the translators who adopt foreignisation sourcers as they normally lean more towards the author and the source language, thus, leaving deliberately their final product with a subtle touch of foreignness in it. Translators who follow domestication, according to Newmark (1988), are targeteers, since they display a greater propensity towards the target language readers and make adjustments in the target text that closely resemble the features of the target language. Landers (2001, p. 50) seems to occupy middle ground as far as this issue is concerned as he claims that in real- 
world translating there is "an irregular swing, sometimes in a single paragraph, between favouring the author and favouring the reader". In other words, the translator very often has no choice but to make use of both domestication and foreignisation alternatingly even within a single translation.

Understandably, these are by no means the only requirements that literary translators should meet. What follows in the next section is an overview of some of the most common aspects that translators are expected to tackle in doing literary translation, irrespective of the genre they are working on.

\section{Some common pitfalls in literary translation}

Regardless of what genre a literary piece belongs to - prose, poetry or plays the translator is very likely to encounter issues such as discerning and rendering the author's style and the subtext itself. Moreover, the translator's dilemmas may extend to the title of the work; the choice of lexis particularly expressive lexis such as slang and expletives; the use of culture specific terms and puns. The following sections discuss these issues in turn.

\section{Translating subtext and author's style}

The translator should be adept at discerning the author's style. The author's style comprises the authors' choice of words, length of sentences, sentence structure, paragraph division, the use of figures of speech, etc. Each author has their own writing style. The dilemma that arises among translation theorists is whether the translator should emulate the author's style, i.e. make attempts to disappear and become indistinguishable from the style of the author or perhaps change the author's style replacing it with his/her own. Landers' position (2001, p. 90) is that "the translator should adopt the style of the author - now terse, now rambling ... but always as faithful to the original as circumstances permit".

Mihajlovski's translations of Shakespeare into Macedonian are a good example of how this can be done. Kitanovska-Kimovska \& Gjurchevska-Atanasovska (2018) compare Mihajlovski's translations of "Hamlet" and "A Midsummer Night's Dream" with the translations of the same plays done by another Macedonian translator. The analysis focuses on a very salient feature of Shakespeare's lexis: words derived by compounding and conversion. Their results suggest that Mihajlovski has made a conscious effort to reproduce Shakespeare's style not only by using compounding and conversion as a means of lexical innovation in places where they are used in the original text, but also by adding new ones in places where they are not found in the source text (ibid., p. 81). For example, Mihajlovski matches Shakespeare's compound "fear-surprised eyes" with his own compound coinage “стравоококорени очи” (stravookokoreni ochi - back- 
translated as: fear-goggled eyes). Following Shakespeare's model, he also adds the compound “љуби-сокот" (ljubi-sokot - back-translated as: the love-juice) where there is no special innovation in the Shakespearean text (ibid.). These are just two examples out of numerous ones found in Mihajlovski's translations.

Paul (2009, p. 44) goes slightly further and raises another style related-issue - "What happens when there is a purposeful stylistic awkwardness in the original which would simply not work in the target language?". In that context, Paul (ibid.) recommends that the translator should try "to convey the sense of awkwardness in other ways". A proposal of how this can be done is provided by Zorica Petkovska (2017) in her discussion of the options for the Macedonian translation of the Nadsat jargon in Anthony Burgess' A Clockwork Orange. Notably, Burgess' Nadsat jargon is largely based on the Russian language, which defamiliarises it for the English reader and makes it stand out against the English text. Based on Russian as a foreign language which is unintelligible, distant and even frightening, the Nadsat jargon serves the purpose of scaring the ordinary English reader and attracting young English people. When the book is to be translated into Macedonian, the fact that Macedonian and Russian are Slavic languages and some words are the same or strikingly similar, the effect the Russian has in the English text would be lost if it is kept unchanged. Therefore, Petkovska suggests two broad strategies for conveying the stylistic awkwardness of the Nadsat jargon. One is to use Russian synonyms that are not the same or similar to their Macedonian counterparts and would, therefore, be equally foreign to the Macedonian reader. For instance: "mozgvilina" for "mozg" (brain), "osvedomlenie" for "gazeta" (newspaper) (ibid., 154-155). The second strategy she suggests is to use a different foreign language, for example, Japanese, and use Japanese words to replace the Nadsat words. Thus, among, other examples she provides, she suggests the Japanese word "gen" for the Russian "vek" (human/man) (ibid., 156) to preserve the defamiliarizing effect in the Macedonian translation.

Subtext is the implicit and the underlying meaning of a text. In order for one to grasp the subtext of a particular literary work one must be able to read carefully and read between the lines. The subtext is in fact the hidden message that the text imparts. The subtext may be sexual, political, religious, etc. Thus, for instance, the fairy tale "Little Red Riding Hood", Landers (2001, p. 126) claims, has a sexual subtext, intended to forewarn young girls of sexual predators.

Not all writings have a subtext, though. Only the masterfully written pieces have a subtext. Literary translators' task is to discern the subtext, if present, and to choose lexis very carefully so that they could reproduce it faithfully in the target text.

The example of the Mihajlovski's translation of Hamlet's dialogue with Ophelia into Macedonian is a case in point (Kitanovska-Kimovska, 2014). Notably, in 
order to reproduce Hamlet's bitterness, sarcasm and irony in addressing Ophelia, the translator reproduces the pun by using different words than the ones used by Shakespeare while conveying the same meaning and effect. Shakespeare uses puns on the words "country matters" and "nothing" to refer to "obscenities" and "the female sex organ", respectively. The Macedonian translation uses the colloquial words "онаа работа" (onaa rabota - back-translated as: that job) and "такваата" (takvaata - back-translated as: the such thing), which, apart from their primary meanings, are used to refer to "intercourse" and "the female sex organ", respectively. Thus, although the Macedonian wordplay is not the same as the English one, the context in which it is used and the effect it achieves are the same (ibid., p. 312). The translator has managed to identify the subtext, i.e. the sexual allusions Hamlet is making and has put an effort to convey them in his translation. Judging by our standards, he has been very successful in doing so.

\section{Translating titles}

Translating the title of a specific literary piece, no matter what genre it belongs to, places a heavy responsibility on the translator. Newmark $(1988$, p.56) argued that the translated title "should usually bear some relation to the original, if only for identification", but it should also "sound attractive, allusive, suggestive" to attract the potential readers. A clear and appealing title is crucial not just because it adds to the attractiveness but also to the saleability of the work. Landers's (2001, p. 140) position regarding the translation of titles of literary works is that the translator has the option either to retain it, or modify it, or, as the very last resort, discard it in accord with the exigencies of taste and marketplace. In that context, he admits that sometimes the title is straightforward and the decision is often automatic, but adds that, often times, titles are altered beyond recognition. His recommendation is that a title should be changed only when it cannot be left unchanged, because of cultural, linguistic, historical and geographical disparities between the source and the target language. Thus, for instance, place names in a title can be very troublesome. The same is the case when the title relates to some cultural references or literary allusions. In those cases, the translator is advised to save the selection of the title for last or until inspiration strikes. What is needed in selecting the title according to Landers (ibid.) is flexibility and imagination as well as apprehension of a work's thematic sinews and textual subtleties such as themes and subtext.

Similar positions to those of Landers are expressed in Paul (2009). Namely, Paul agrees that some titles "lend themselves neatly to translation", but he further adds that "literal translation is often a dreadful mistake when it comes to titles", and that "editors and translators must be prepared to be creative" when it comes to rendering titles $(2009$, p. 42$)$. 
One such example of creative translation of a title is the Macedonian translation of Oscar Wilde's "The Importance of Being Earnest". Kitanovska-Kimovska \& Neshkovska (2016, p. 122) argue that the Macedonian translator's "equivalent effect" translation strategy is an ingenious solution to preserving the dramatic irony which is central to the play. Notably, Wilde's pun on the meaning of Earnest (used as a proper name and an adjective meaning "serious") in the Macedonian translation is rendered as "Bogumil". This solution keeps the pun because Bogumil is a Macedonian proper name carrying the meaning of "dear to God". This change may seem dramatic, but it is also necessary in order to reproduce in the target text the same semantic and pragmatic effects which are produced in the source text. Without it the target text reader would miss a lot of the humour and satire of Wilde's original text.

Another interesting example is the Macedonian translation of the title of Michelle Obama's memoir "Becoming", released in 2019. The literal translation of the term 'becoming' in Macedonian would be 'настанување' (nastanuvanje). However, this word is not normally used in the context of one's personal experiences. In order to avoid the awkwardness that the literal translation of the title would cause, the translator opted for a modification of the title based on the content of the book and translated it as "Mojata prikazna" (back-translated as "My story"). This solution, however, does not fully encompass the meaning of 'becoming' in the sense of undergoing a profound personal transformation in the course of one's lifetime. To compensate for the loss, the translator also decided to leave the original title on the front page (Becoming) alongside the translated title (My story).

\section{Translating slang}

Nothing in language changes more rapidly than slang, the language of closed groups of people (e.g. teenagers, adolescents, criminals, etc.) who create it in order to communicate with the members of their group and to exclude the others as outsiders (e.g. parents, authorities, etc.). Due to its novelty and freshness, slang is a pertinent feature of literary works, too. One difficulty that arises in relation to translation of slang is its temporariness, i.e. the fact that it changes very rapidly from one generation to the next. Paul (2009) explains that in some translations you can almost identify the year, if not the month, in which they must have been translated mainly due to the slang terms employed. Slang is also one of the reasons why some works of literature require retranslation.

Another important slang-related issue, in the context of translation is that very often it is extremely difficult to find similar slang terms in the target language as the slang terms used in the source text are usually a product of a completely different social reality (Brodovich, 1997). Landers (2001) points out that it is 
only heavy exposure to the foreign culture that alerts translators to the very rapid changes that occur in such speech patterns as slang. He further adds that "while we can pick up slang terms by reading, nothing except living in the culture can inform us of which terms have fallen into disuse" (2001, p. 77).

A good example of how slang can be translated in literature is provided by Gjurchevska-Atanasovska \& Sazdovska-Pigulovska (2017), who discuss the Macedonian translations of Carver's short story collection "What We Talk about When We Talk about Love" and suggest their own translation solutions. For instance, for the slang term "It's in the bag" used to refer to a girl, meaning "certain to be won over", they suggest colloquial expressions like "мојa e (moja e - back-translated as: she is mine)" оr "печена е (pechena e - backtranslated as: she is roasted)". These solutions are stylistically more appropriate in the context rather than the literal translation "Ја имам в торба" (Ja imam v torba - back-translated as: I've got her in my bag) (ibid., p. 389). GjurchevskaAtanasovska \& Kitanovska-Kimovska (2018) also discuss examples of slang translation illustrating how slang can be adequately rendered conveying the same colour and richness as the original English slang words. For example, the slang term "cop" used to refer to a policeman in Bukowski's book "The Most Beautiful Woman in Town" is translated with the slang term "цајкан" (cajkan) in the Macedonian translation of the same book or the slang expression "to hit it hot", which means "to have, to possess", is translated with the colloquial word “ќари” (kjari) meaning “to earn” (ibid., pp. 105-106).

\section{Translating expletives}

Expletives or profanities are also known as four letter words, dirty words, curses, swear words, crude or vulgar language and are generally considered as strongly impolite and offensive. When people use swear words, which, in essence, are words and expressions related to body functions, sex and religion, they do it in order to shock and offend, to be aggressive or provocative and to draw attention to themselves (Andersson \& Trudgill, 1990, p.14). Although many people find profanities shocking and unacceptable, using obscene words is part of language, culture and, consequently, literature. Literary translators might find themselves faced with the dilemma of what to do with expletives; some of them are undoubtedly considering the option of not translating those words at all because of their moral principles. Landers (2001, p.151) suggests that the translator should "do the same conscious job of translating as with any other text", because according to him "the translator should be a professional and is not expected to apply his own standards of decency and morality to the task". 
As to the translation of profanities in literary works, what is outright evident is that word for word translation is not most appropriate because the final outcome will sound ridiculous and meaningless. Or as Dobao Fernandez (2006, p.139) notes:

in the translation of swearing the literal and referential meaning of the original lexical item are of little relevance... It is the emotional charge of the swear word that needs to be taken into account in order to express in the target language the same emotion and attitude the speaker intends to express in the source language and thus produce in the receptor of the translation the same impact the original swear word produces in the receptor of the source text.

Gjurchevska-Atanasovska and Kitanovska-Kimovska (2018) also suggest that thought for thought translation should be used in such cases instead. In other words, the main purpose is to translate not what the author has said but what he/she has meant. They provide examples from the Macedonian translations of Bukowski's book "The Most Beautiful Woman in Town" and Carver's short story collection "What We Talk about When We Talk about Love" to support this approach. Bukowski's expression "god damn it" used as a swear expression is translated with a suitable swear expression in Macedonian "да му се сневиди" (da mu se snevidi - back-translated as: let him/her lose his/her sight) (ibid., p. 106). They also suggest that Carver's vulgar expression "there was no boss to get on your ass" should be translated with a similar vulgar or colloquial expression, such as "не ти стои над глава" (ne ti stoi nad glava back-translated as: s/he doesn't hang over your head), "не ти дише во врат" (ne ti dishe vo vrat - back-translated as: s/he doesn't breath into your neck), "не ти досаѓa” (ne ti dosagja - back-translated as: s/he doesn't bother you), “не те гњави" (ne te gnjavi - back-translated as: s/he doesn't pester you), "не те замара" (ne te zamara - back-translated as: s/he doesn't tire you), "не те дави” (ne te davi - back-translated as: s/he doesn't torture you), rather than the literal one "каде што газдата не ти беше зад газот" (kade shto gazdata ne ti beshe zad gazot - back-translated as: where the boss wasn't behind your ass) (ibid., p. 107).

\section{Translating culture-related terms}

Very often difficulties in literary translation are bound to arise due to terms which refer to cultural artefacts not found in the target culture. The greater the cultural distance between the source and target culture, the more difficulties the translator will face when rendering these terms into the target language.

Culture-specific terms includenames of people, objects and institutions notreadily understood by another culture. These are often meaningless to the target language readers. Newmark(1988) distinguishes five domains for classifying culture words: 
1) ecology (flora, fauna, winds, plains, hills); 2) material culture (food, clothes, houses and towns, transport); 3) social culture (work and leisure); 4) organisations, customs, activities, procedures, concepts (political and administrative, religious, artistic, etc.), and 5) gesture and habits. Landers (2001, pp. 93-95) proposes three options for dealing with culture specific terms: a) footnotes; b) interpolation, c) omission. When it comes to footnotes particularly in fiction, he cautions translators as footnotes can destroy the aesthetic effect of the work, especially if used frequently. In such cases, he recommends using endnotes or a glossary at the end of the book instead. Interpolations, on the other hand, are depicted as adding a parenthetical word or phrase as unobtrusively as possible in order to explain a culture-specific term in the target text. Landers (2001, p. 94) treats this strategy as 'a cosmetic surgery' and advises translators to think how important the given word to which they plan to attach an interpolation is, prior to reaching the decision to interpolate. He also emphasises the advantage of this strategy as after a term is explained the first time, it frees the translator "to use the ST term, which is likely to be more concise and certainly more denotative than its translation". Omission, on the other hand, does not refer to leaving the term out. According to Landers (ibid.) it rather refers to omitting an explanation, i.e. it means leaving the reader to his/ her own devices in grasping the meaning of an unfamiliar term.

Another possibility for the translator is to adapt the source text culture to the target text culture replacing source culture-specific terms with target culturespecific terms in order to preserve the same effect on the reader. KitanovskaKimovska and Neshkovska (2018) have found adaptation to be the most dominant translation strategy used for the Macedonian translation of Oscar Wilde's play "The Importance of Being Earnest". In order to achieve the play's pragmatic goal and to preserve the pun in the play's title, the translator has shifted the action from England to Macedonia and the characters have become Macedonians rather than Englishmen; the 19th century English society has become the 20th century Macedonian society and the Wilde's satire of Victorian England has turned into a comment on the Macedonian post-independence society (ibid., p. 257). Thus, all English street names, food items, institutions have been replaced by Macedonian ones. For example, "Half-Moon street" is rendered as "улицата JHA" (ulicata JNA - back-translated as: the street JNA); "cucumber sandwiches" as "кифлички со кашкавал" (kiflichki so kashkaval - back-translated as: rolls with yellow cheese); "the Metropolitan Police" as "MBP" (MVR - acronym for the Macedonian Ministry of Interior). Also, all social, political and temporal references have been replaced with ones relevant to the Macedonian context, so "French drama" has become "српско-хрватска драма" (Serbo-croatian drama), "Tories" have become "Црвени како нас" (crveni kako nas - back-translated as: the red ones like us), "Rectory" has become "Црквата" (Crkvata - backtranslated as: the Church) and many more (ibid., pp. 252-253). 


\section{Translating wordplay}

The employment of wordplay in literary works results in producing a humorous effect. Puns are a special type of wordplay based on ambiguity. To put it differently, a pun is created when a double meaning is created in a context by exploiting words that differ in meaning but are similar in pronunciation and/or spelling. The pun is effective when the context allows for a double-reading to be triggered.

In any case, the translation of puns in literary works can be extremely challenging, if not impossible. Puns are presumably untranslatable as it is very difficult to transfer a pun into the target language with lexemes equivalent to those in the source language (Vandale, 2010). Delabastita (1997) discusses a range of pun translation techniques: a) pun to pun; b) pun to punoid; c) pun to non-pun; d) pun to zero, e) non-pun to pun, etc., that can help in overcoming this problem.

Paul (2009, p. 49) confirms that puns are obviously specific to their original language and that an equivalent has to be found in the target language. But he also admits that sometimes "if these simply don't work, they need to be cut out, or a completely different play on words has to be invented to retain the liveliness of the original wordplay".

In translating puns, evidently, it is vital to achieve an equivalent effect in the target text. The target text-oriented approach (domestication) is preferable if the focus is on the production of as close an effect on the target audience as the effect obtained on the source audience. The examples of the Macedonian translations of "Hamlet" and "The Importance of Being Earnest" we discussed above are a good illustration of this approach. Notably, in both cases the translator has opted for a target language based puns. He has followed the original model and has changed the vocabulary but preserved the effect so that the Macedonian readers would be equally entertained as the readers of the original English texts. In view of the difficulty involved in conveying puns due to the structural and lexical differences between both languages, Kitanovska-Kimovska (2014) mentions that translators sometimes add puns in places where they are not found in the original text to compensate for the losses they have made elsewhere in the text. She provides the example of Bogomil Gjuzel's translation of "A Midsummer Night's Dream", where he adds the pun on "морално" (moralno - back-translated as: moral), which can be interpreted both ways: in its correct meaning 'following moral rules' (pronounced with a stress on the first syllable) or in its colloquial meaning 'obligatory' (derived from the verb "мора" (must) and pronounced with a stress on the second syllable) (ibid., p. 312). Used by one of the socially and intellectually deprived characters in the play, the pun skilfully adds to the humour of the scene. 


\section{Conclusion}

Starting from the position that literary translation presents numerous challenges to the translator, we have attempted to provide an overview of some key aspects of literary style and how they might be tackled in translation. The paper presents the views of translation theorists with respect to the pitfalls of literary translation as well as the findings of empirical studies of literary translations of English source texts into Macedonian. Aspects such as style, subtext, book titles, slang, expletives, culture-specific items and wordplay are discussed in more detail. Examples are provided to illustrate how they might be handled creatively by translators who are aware about their significance and contribution to the overall effect on the reader. Whereas the topic of literary translation is broad and a paper of this size cannot possibly address all relevant issues in sufficient detail, the discussion, nevertheless, benefits novice and aspiring literary translators and can serve as a good starting point in training literary translators.

\section{References:}

Andersson, L., \& Trudgill, P. (1990). Bad language. Oxford: Basil Blackwell.

Arsova-Nikolich, L. (1999). Preveduvanye. Teoriya i praktika. Skopje: Univerzitet „Sv. Kiril i Metodiy".(Macedonian)

Brodovich, O. (1997). Translation theory and non-standard speech in fiction. Perspectives: Studies in Translatology 5. (1), 23-31.

Delabastita, D. (1997). Traductio: Essays on punning and translation. Manchester: St. Jerome; Namur: Presses Universitaires de Namur.

Dobao Fernandez, A. M. (2006). Linguistic and cultural aspects of the translation of swearing: The Spanish version of Pulp Fiction. Babel 52:3, 222-242. DOI: 10.1075/ babel.52.3.02fer.

Gyurchevska-Atanasovska, K., \& Sazdovska-Pigulovska, M. (2017). When translation goes wrong: Translating idiomatic expressions. Proceedings of the ESIDRP International Conference: English Studies at the Interface of Disciplines: Research and Practice (ESIDRP) (1 $1^{\text {th }}-13^{\text {th }}$ March 2016, Skopje, Republic of Macedonia). Skopje: Ss Cyril and Methodius University in Skopje, Blaze Koneski Faculty of Philology, 383-394.

Gyurchevska-Atanasovska, K., \& Kitanovska-Kimovska, S. (2018). Stilot i preveduvanyeto niz prizmata na kognitivnata uloga na preveduvachot kako primatel na tekstot pri kreativniot proces. Palimpsest, III, 6. Shtip: Univerzitet „Goce Delchev“ - Shtip, Filoloshki fakultet, 101-111. (Macedonian)

Kitanovska-Kimovska, S. (2014) Preveduvanye igra na zborovi: strategii i faktori. Proceedings of the International Applied Linguistics Conference: Practice in Language, Language in Practice (PLLP) (7-8 June 2013 Skopje, Republic of Macedonia). Skopje: FON University, 304-316. (Macedonian) 
Kitanovska-Kimovska, S., \& Neshkovska, S. (2016). The importance of being earnest: Strategies for translating irony from English into Macedonian. Acta Neophilologica 49, 1-2, 109-125 DOI: 10.4312/an.49. 1-2. 109-125.

Kitanovska-Kimovska, S., \& Neshkovska, S. (2018). Handling of culture-specific terms in translation. Conference Proceedings of the Third International Scientific Conference FILKO, Philology, Culture and Education, 26-27 April 2018, Shtip. Shtip: Goce Delcev University, 247-258.

Kitanovska-Kimovska, S., \& Gjurchevska-Atanasovska, K. (2018). The norms at play in the Macedonian literary system: An analysis of the role of Mihajlovski's Shakespeare in Macedonian. TranslatoLogica Vol. 2, 74-93.

Landers, E. C. (2001). Literary translation. A practical guide. Multilingual Matters LTD.

Newmark, P. (1988). A textbook of translation. New York: Prentice-Hall International.

Obama, M. (2020). Becoming. Mojata prikazna. Skopje: Ars Lamina - publikacii, Ars Libris

Paul, G. (2009). Translation in practice: A symposium. London: Dalkey Archive Press.

Vandaele, J. (2010). Humour in translation. In Gambier, Y. \& van Doorslaer, L. (eds.) Handbook of translation studies. (pp. 147-52). Vol 1. Amsterdam \& Philadelphia: John Benjamins.

Petkovska, Z. (2017). Squeezing the Clockwork Orange in the kitchen of Slavic languages: Translating the Nadsat jargon in Antony Burgess's novel. Proceedings of the ESIDRP International Conference: English Studies at the Interface of Disciplines: Research and Practice (ESIDRP) (11th -13th March 2016, Skopje, Republic of Macedonia). Skopje: Ss Cyril and Methodius University in Skopje, Blaze Koneski Faculty of Philology, pp. 149-159

Venuti, L. (2008). The translator's invisibility: A history of translation (2nd ed.). New York: Routledge. 